INTERNATIONAL JOURNAL OF MULTIDISCIPLINARY RESEARCh AND ANALySis

ISSN(print): 2643-9840, ISSN(online): 2643-9875

Volume 04 Issue 09 September 2021

DOI: 10.47191/ijmra/v4-i9-18, Impact Factor: 6.072

Page No.- 1318-1326

\title{
Uses Gratification Theory and Village Cooking YouTube Channel- A Discourse
}

\section{P John Britto}

Madurai kamaraj university India.

ABSTRACT: Viewers of youtube channel, choose the content freely to satisfy their needs. They like a video or dislike a video based on their likes and dislikes, thus empowering audience over media to give their feedback. More than this audience can give their comments over the content of the video. This paves for active participation of audience as Uses Gratification Theory (UGT) postulates. The audience also has the power to share the video to other platforms to show how their physical, psychological and social needs were satisfied and so others could get satisfied. Village Cooking YouTube channel has been taken for experiment to evaluate the concepts of UGT.

KEYWORDS: Uses gratification theory - YouTube - Village Cooking Channel - Needs satisfaction

\section{A. INTRODUCTION}

Uses Gratification theory states that people actively seek out specific media to satisfy specific needs. The theory explains that audience is free to choose the options from the content available in front of them and that each one has different motive of satisfying their needs by choosing such specific media. The spectrum of needs ranges from physical, psychological and social, consolidating cognitive, affective and behavioural needs. Village Cooking Channel is (VCC) a cooking channel from India and stands as the first youtube channel to get diamond button from YouTube, crossing one crore subscribers. This paper tries to look into various concepts of UGT and trying to have a discourse of UGT, in relationship with VCC.

\section{B. USES GRATIFICATION THEORY}

Wikipedia explains Uses Gratification Theory (UGT) as an approach to understanding why and how people actively seek out specific media to satisfy specific needs. Diverging from other media effect theories that question 'what does media to the people?', UGT focuses on 'what do people do with media?' The driving question of UGT is: Why do people use media and what do they use them for? UGT discusses how users deliberately choose media that will satisfy given needs and allow one to enhance knowledge, relaxation, social interactions, companionship, diversion or escape. [1]

\section{Role of Audience}

Uses Gratification Theory gives its thrust on the role of audience. It propels the following ideas:

1. Audience's Freedom: Various media gives various content but the audience are the ones who choose the specific content and thus specific media.

2. Audience's Motive: The audience choose specific content and so specific media in order to satisfy their specific needs.

3. Variety of Needs: Their needs may vary from cognitive needs (increasing their knowledge), affective needs (entertainment), behavioural needs (changing their actions), social needs (increasing interactions and relationships), psychological needs (mental satisfaction or diversion)

4. Paradigm shift: The perspective is not from the media to people but from the people to media. It is not what media does to the people but what people do with media that matters.

So, it is clear that the audience as consumers have clear motive in selecting a particular media and particular content. Gusfield (1994) opines that unlike other theories concerning media consumption, UGT gives the consumer power to discern what media they consume, with the assumption that the consumer has a clear intent and use. This contradicts previous theories such 


\section{Uses Gratification Theory and Village Cooking YouTube Channel - A Discourse}

as mass society theory, that states that people are helpless victims of mass media produced by large companies; and individual differences perspective, which states that intelligence and self-esteem largely drive an individual's media choice. [2]

\section{Goals for media use}

People are no longer passive audience, getting affected by mass media who control the thought of mass and so become victims of mass media. Now they have choices and have power in exercising their freedom to choose the type and content of media. People choose particular media to satisfy their particular needs and not by individual differences perspective, intelligence and self-esteem. These needs can vary from social needs and psychological needs. They are the base for media production, the content and methodology. The media serves the people. In one way, it can be understood that the people are the masters and the media are the servants.

Katz, Blumler, and Gurevitch synthesised that UGT's approach was focused on "the social and psychological origins of needs, which generate expectations of the mass media or other sources, which lead to differential patterns of media exposure (or engagement in other activities), resulting in need gratifications and some other consequences, perhaps mostly unintended ones. [3] This explains clearly that there are definite goals for audience to use specific needs. Denis (2010) in his book Mass communication theory: an introduction, lists the following goals for media use.

According to the research, goals for media use can be grouped into five uses. The audience wants to:

1. be informed or educated

2. identify with characters of the situation in the media environment

3. simple entertainment

4. enhance social interaction

5. escape from the stresses of daily life [4]

How could the above needs explained by Denis (2010) and the needs explained by the founding authors of UGT be classified? West and Turner (2010) is of the opinion that Abraham Maslow (1954) comes in handy to stratify the needs.

\section{Hierarchy of Needs}

According to West and Turner (2010), UGT was an extension of Needs and Motivation Theory, as outlined by Abraham Maslow in 1954, which argues that people actively looked to satisfy their needs based on a hierarchy. These needs are organised as Maslow's Hierarchy of Needs in the form of a pyramid with the largest, most fundamental needs at the base and the need for self-actualisation at the top. From the bottom-up the pyramid contains Biological/Physical, Security/Safety, Social/Belonging, Ego/Self-Respect and Self-actualisation at the top. [5]

For physiological and safety needs of things like food, water, warmth, security, safety and rest one needs to be informed or educated to know how to cultivate food or build a house of warmth. These are the cognitive needs to enhance knowledge and behavioural needs to change their behaviour. UGT states that people who would like to satisfy their physiological needs, they search for media that would cater to their needs. It means that people have the choice to choose the appropriate media and gratify their needs.

For psychological needs of belongingness and love needs, such as relationships, friendship and of esteem needs such as prestige and feeling of accomplishment, people need to feel with emotions. This is the affective need to enhance their emotional intelligence and social need to enhance their interactions. It gives them social relationships, companionship and relaxation. It entertains them and help escape from the stresses of daily life.

For self-fulfilment needs of achieving one's full potential including creative activities, people should get enlightened. The media has contents to satisfy people's creativity and achieve their self fulfilment.

When traditional media such as newspapers, radio and television try to satisfy peoples needs, internet has grown as the preferred media to gratify peoples needs recently. 


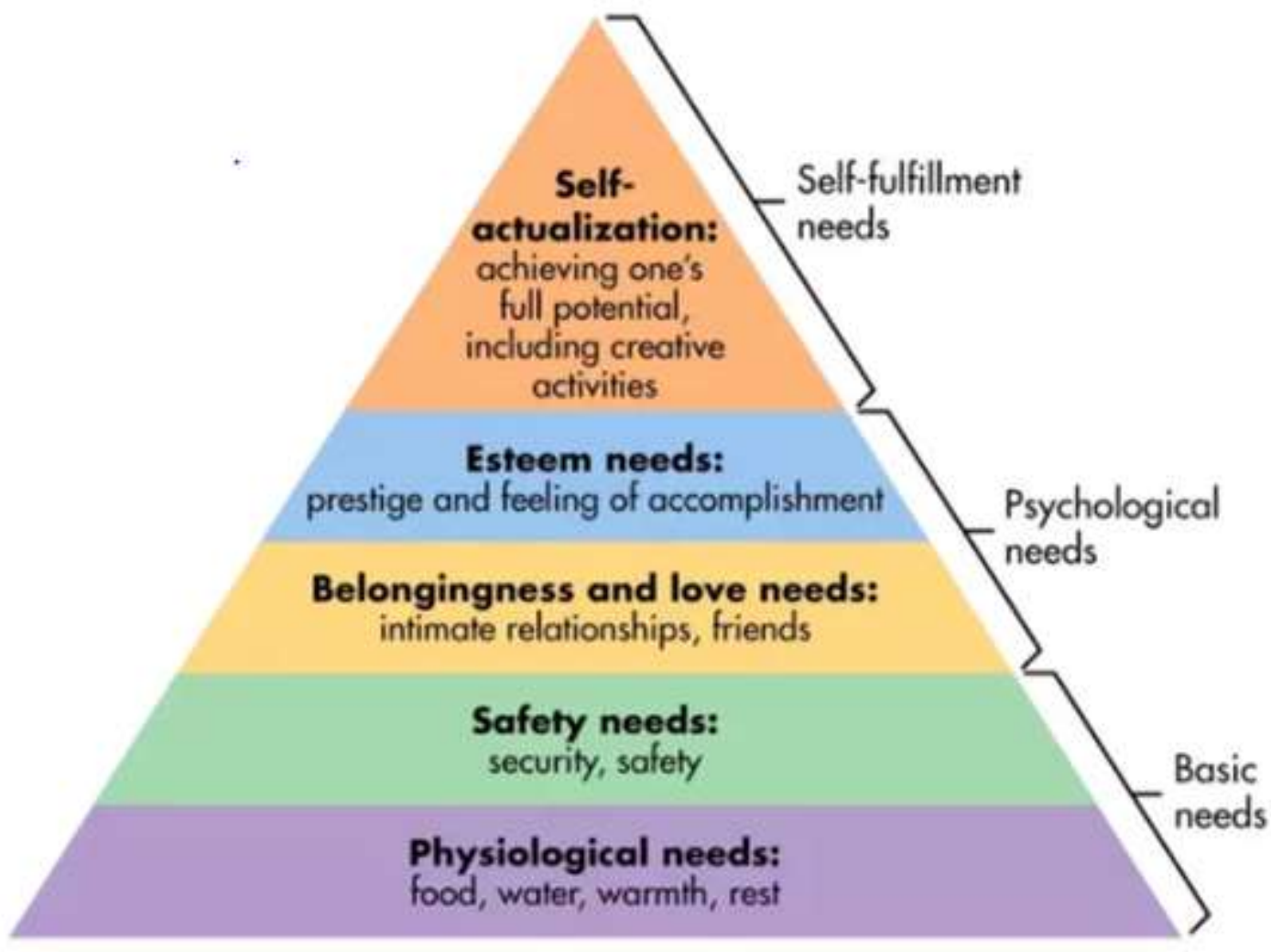

Diagram: Abraham Maslow's Hierarchy of Needs

\section{Internet and UGT}

Thomas et al. (2004) notes that the Internet provides a new and deep field for exploring UGT. It was found to have three main categories of gratifications: content gratification, process gratification, and social gratification.

Content: Uses for the Internet include the need for researching or finding specific information or material, which are gratified with content.

Process: Users gain gratification from the experience of purposeful navigating or random browsing of the Internet in its functional process.

Social: Uses encompass a wide range of forming and deepening social ties. [6]

Unlimited content is available in internet and is growing every minute. The search engines help people to research and find specific information or entertainment. People only have to navigate through various options, via either through random browsing or purposeful search and get their satisfaction of finding the content and consuming it. It is like a cow looking for the green pasture, available abundantly in front of it and need to look for the right grass to get the satisfaction of eating it. The content is the grass. The people are the cows. But is it all? No. There is more to it. The cows can get introduced to friendly cows and get the satisfaction of relating with them. That is the social ties that internet could bring in the lives of the people. That is the power of

Louis (2013) rightly states that recent research has looked at social networking services, personal and subjectbased blogs, and internet forums put together to study the U\&G in posting social content, the relationship between gratifications and narcissism, and the effects of age on this relationship and these gratifications. Users have motivations of the following overall:

1. Social and affection

2. Need to vent negative feelings

3. Recognition

4. Entertainment

5. Cognitive needs [7] 


\section{Uses Gratification Theory and Village Cooking YouTube Channel - A Discourse}

It can be understood that uses and gratification theory, in total, explains that people at various stages have various needs, such as physiological needs, psychological needs and social needs and that media, especially internet, has the content for people to freely browse through to satisfy their needs. Since YouTube is a growing social media in internet, youtube is taken for understanding uses gratification theory and how it helps people get the satisfaction. A particular channel called 'Village Cooking Channel' (VCC) is taken for experiment as it stands 93rd rank in all over India and has 1crore and 29 lakhs subscribers as of today.

\section{VILLAGE COOKING CHANNEL}

Village Cooking Channel (VCC) is one of the thousands of YouTube channels in YouTube. Firstly a brief about YouTube will help in understanding how these channels work and Secondly a brief about VCC will help in understanding the history and growth of VCC.

\section{YouTube - A Brief}

YouTube can be defined as video sharing website that allows users to watch, upload and comment on videos. Established in 2005, YouTube was co-founded by Chad Hurley, Steve Chen and Jawed Karim. It is owned by Google Inc., which displays its ads in the website's pages. YouTube is available in 14 different languages. [13]

YouTube is a revolutionary invention to share and view original videos for information, entertainment and education. In fact the first video was posted in YouTube on 23rd April 2005. [14] It has grown into a big store of videos, globally accessible by people of all walks of life from every country. As of September 2021, there are more than 500 hours of content uploaded to YouTube each minute, and one billion hours of content are watched on YouTube every day. [15]

Five hundred minutes of videouploaded to YouTube every minute equates to approximately 30,000 hours of video uploaded every hour. In 2019, YouTube reported two billion people logged in to the platform daily and one billion hours of video watched per day. $82 \%$ of people use YouTube as a source of entertainment. $37 \%$ of viewers ages 30 to 49 use Youtube as a news source.As of 2020, YouTube was the fifth most used social media platform for marketers after Facebook, Instagram, LinkedIn, and Twitter. The majority (59\%) of YouTube customers consist of males, while $41 \%$ female. 25 to $34-$ year-olds make up 32\% of Youtube customers, making them the most dominant age group. In 2021, there are approximately 1.86 billion YouTube users worldwide, up from 1.47 billion in 2017. It's estimated that by 2022, there will be 210 million viewers in the U.S., up from 192 million in 2018. [16]

\section{Village Cooking Channel (VCC)}

Nahla (2020) in his article in The Hindu writes that 'Ellarum vaanga, always welcomes you! 'Fans of Village Cooking Channel (VCC), the Tamil YouTube channel that has more than 3 million subscribers, know that these words, yelled out enthusiastically by its team of five chefs and cameraman, are the start to something worth feasting on, if not physically, at least with one's eyes. But now, according to Social blade, in 2021 its subscribers grew into one crore and counting and thus got their diamond button from YouTube.

\section{History of VCC \& Passion for Cooking}

VCC was founded by Subramanian, Murugesan, Ayyanar, Tamilselvan, Muthumanickam and Periyathambi from Chinna Veeramangalam village, Pudukkottai district of Tamil nadu state. VCC posts three to four videos per week of cooking videos. The team earns around Rs.7 lakh per month from the advertising revenue generated by YouTube viewings.

Food plays a big role in village life, and men take over kitchen duties when the womenfolk are out in the fields, says Subramanian. "After television, cooking was the biggest form of entertainment for us when growing up. In Chinna Veeramangalam, I would say every man has learned as many recipes from his mother as any woman, from an early age."This came in handy in 2018, when Subramanian, who has an M Phil in Commerce and previous web design experience, decided to produce online cookery videos. "My cousins were between jobs, and hoping to go abroad. That is when I decided to showcase the food we eat, cooked in our unique style, with thatha (grandfather) leading us. VCC's viewership started growing when we stopped imitating other programmes," he says. Its near-theatrical production style has won it many accolades, the most recent being the Black Sheep Award for Best Food Programme in February."But before its launch, all of us were readying to leave for abroad. I was running a website that showcased designs of freelancers for sale. In 2016, I sold it off. For two years, I was jobless and did not know what to do. My brother had done his B.Com and was preparing to fly abroad. Another one had a degree in 


\section{Uses Gratification Theory and Village Cooking YouTube Channel - A Discourse}

Hotel Management. We were all set to fly. It was by sheer chance that we decided to try our luck with a YouTube channel," says Subramaniam.

Subramanian's three cameras focus not just on the cooking, but also the verdant surroundings where firewood stoves are set up from scratch. The team usually shoots in the open, near the fields in 10 neighbouring villages, transporting its equipment (including traditional stone grinders) in a van. Since Periyathambi is not used to cooking for less than 100 people, the team arranges free banquets for charity homes to share the food they prepare.

"We started with recipes that are common in our village, such as winged termites fried with puffed rice, and crabs, snails and fish caught in field bunds," says Subramanian. "These dishes have a nostalgic value for our Tamil viewers, especially for those who have migrated from villages to urban areas."But it's not all rustic cuisine; Muthumanickam has studied catering in college, and is the brains behind some of the more exotic dishes like Arabian mutton biryani cooked with two full goats, which garnered over 21 million views after it was uploaded last March.There are some surreal scenes too, such as a giant cloth ball of chenna (cheese curds made by splitting milk with lemon juice) hanging out to drain like an outlandish fruit on a tree while the team gets ready to make rosogollas in the fields.

\section{Fan Following}

Some of the chefs have their own fan following - Ayyanar's skill with the stone grinder (ammi) gets many comments, while Muthumanickam's expert onion chopping is also popular. The team avoids using modern conveniences like pressure cookers and electric mixers.

\section{First difficult days and the turning point}

The first eight months were a struggle, he adds. "We uploaded very regular, very professional cooking videos. These videos did not cross a few hundred views." The first breakthrough came in 2018, after Cyclone Gaja struck the coast. "For 12 years, we were hit by drought. In 2018, for the first time in many years, we saw many winged termites in our village. Our childhood was all about catching them and eating them, about traditional fish catching etc. So, when we saw the winged termites, we decided to do a video onthat. It was our way of reliving the memories and telling the world the kind of life we had as kids."It became the first video to garner a large number of views. Since then, there has been no turning back. "We really didn't have great expectations from our YouTube channel. Of course, we wanted to earn from it, but didn't fancy ourselves as the best. We still can't believe that our channel has become such a huge hit. To be fair, we expected about a lakh views. That was our biggest dream. Today, our videos have crossed several million views," Subramanian says.

\section{Diamond Button}

In three years, the Village Cooking Channel - launched by Subramanian, his cousins V Murugesan, V Ayyanar, G Tamilselvan and T Muthumanickam and their grandfather M Periyathambi - has achieved the phenomenal feat of being the first Tamil channel on YouTube to secure a diamond button.

\section{Charity}

Once the channel started picking momentum, the team decided to make themselves more useful. "When we started earning from YouTube, we decided to spend some of it on the people who gave us so much love." So, the cooking became bigger. The food was served to elders at a local old-age home. "When we crossed one million subscribers, we did the same. We made biriyani and gave it to the elders at the old age home, along with some essentials for them." Soon, they started to serve the villagers too on the days they were shooting videos for YouTube.

\section{Future Plans}

Congress leader Rahul Gandhi's visit to the team during his election campaign gave the channel another push. "He is a very good cook and when I told him about this channel, it seemed like he was already aware of it. He was keen to visit them," says Congress MP from Karur, Jothimani who had organised the visit. "It was difficult though. At that point of time, the local administration was very hostile and tried to thwart all our programmes. We literally had to sneak him to the place," she adds.

The team was excited. "We had a steady inflow of about 10,000 subscribers every day before his visit. After he visited us, it increased to 30,000 to 40,000 every day," says Subramaniam. In the video, Rahul Gandhi is seen enquiring about the team's interest, and when he learns that they want to travel abroad to demonstrate their cooking, he mentions his 'friend 'Sam Pitroda and tells them that he will help them. In two days after the video was released, Jothimani got Sam Pitroda to do a conference 


\section{Uses Gratification Theory and Village Cooking YouTube Channel - A Discourse}

call with the team. "He made enquiries on what they would require, the countries they plan to visit etc. When the pandemic situation is over, the tour will happen. The team has got their passports ready," she says. "Rahulji even asked me about the progress when I met him in the Parliament."

"We do not want to do this tour in haste. We are willing to wait, but it needs to be done properly," says Subramanian. "Sam Pitroda sir and Jothimani akka are willing to do all the help. For now, we are waiting for our next adventure." [9]

\section{In total, VCC's statistics}

Social blade, an online analytical site for all youtube channels, reports that VCC has uploaded as many as 180 cooking videos. The channel has reached 1crore 29 lakhs subscribers and counting everyday. It has achieved total number of video views of $296,20,07,063$. The channel was created on 25.04.2018 with the channel type as 'How To' in India. In social blade it has 998th rank with video views rank of 1544. Out of millions of channels from India, CCV ranks 93 in India and 'How To' type of videos, it stands as 25 th rank. The standing at the subscriber rank is 1544 th rank as of now.

\section{Transcript of A Video}

Transcript of a video might help in understanding the type of videos published by VCC. As an example, pongal (sweet rice making, during harvest day) cooking video is transcribed here.Tamil people celebrate harvest day for four days in the month of January every year. Out of these four days, celebration of cows, which help farmers in their agricultural works, is called Mattu Pongal. VCC decides to make a video of their celebration of Mattu Pongal and thus show the world how sweet rice is cooked.

The scene starts with giving bath to all cows at the local pond. The camera shows the beautiful splash of water on the bodies of cows and how the artists, the young boys and one old man, wash the cows naturally. Then the cows are walked through the local village road. They are taken to a nearby thatched house, solely built for channel purpose. The artists dress them with new ropes, decorate the cows with holy sandal, kumkum and colourful garland. Then they show how an earthen oven is dug to keep a mud pot for cooking sweet rice. Because it is a start of a new year, everything from the oven to pot should be new. Then they show pouring water and milk into the pot. The cooks then put palm jaggery and country ghee shouting 'Pongalo Pongal' (Rice o! Rice). Some decorate the area with sugarcane while others decorate the ground with kolam (a drawing of lines with dots) and thoranam (a garland of mango leaf and coconut leaf). The sweet rice pot is decorated with ginger plants and rose garlands. After they show how to make the sweet rice, they offer the rice to sun god and serve to the local people, old and young. As said earlier, they serve the food to the nearby old folks home as charity. This is one form of giving to their community from the income that they get.

\section{Interview by Nakkeeran [11]}

An interview taken by a local Tamil Media called Nakkeeran has been transcribed here for better understanding of VCC's history, passion, struggles, achievements and future plan.

Question 1: We can see a lot of smiles in your faces while you cook. How is that you enjoy doing this? What is the secret?

Answer 1: We are all brothers, cousins and family. From our childhood we are together, laugh and live. We do the same while we cook and shoot.

Question 2: Everyone likes eating. But not everyone likes cooking. How is that all of you cook?

Answer 2: All of us have been cooking from our childhood. We like cooking. Our parents used to go as agricultural coolies in the morning and return home very late. We, as children, had to cook rice and curry. If one day, the food is salty, they used to scold us. The next day we will learn and correct ourselves. It is not only our story. It is the story of all the children of farmers. Adding to that our grandfather is a cook. He used to cook for weddings. One of our brother has studied 'hotel management course'.

Question 3: Give a brief of your journey from start to the present.

Answer 3: Our journey as 'Village cooking channel' is just a magic. Because of poverty, we planned to go abroad and search for job. But, we felt if all the males leave the family, a big vaccum will be there. So, we decided to do something here in our area. We decided to start a YouTube cooking channel. We published cooking videos as they show in satellite televisions. We were one among many people. But on one rainy day, there were many winged termites. In our childhood, we used to collect them and cook. So we decided to make a video out of cooking winged termites. That video went viral. From then onwards, our subscribers lead us. They teach us. They direct us. Our success is the success of our subscribers. Our relationship and bond with the subscribers is the cause for our success. 


\section{Uses Gratification Theory and Village Cooking YouTube Channel - A Discourse}

Question 4: Why did you choose to start a youtube channel?

Answer 4: Many are unemployed in districts like Pudukkottai and Ramanathapuram in Tamil Nadu state. At least one or two from each family would have gone out of the village, either to Chennai and other cities in India or to abroad, in search of jobs. That time, One of us is good at starting website and had knowledge of internet and youtube. We also saw that there are many cooking shows in youtube channel going good. Since we were good in cooking, we wanted to integrate both the skills. But we never thought that we would grow to this height. This all happened because we followed our subscribers comments and their requests.

Question 5: Your intro to every channel is very unique? All of you shout 'Ellarum Vanga (All of you come), Always welcomes you". How did you get this idea?

Answer 5: This is also another example of how our subscribers guide us. In earlier videos we never used these sentences. In a video where we cooked fish, one of our members said, Ellarum Vanga, Always welcomes you. Many of our subscribers liked it and asked us to add that in forthcoming videos. In our next video, we used this phrase. The subscribers asked us to say it boldly. So in our other video, we said the phrase boldly. Then our subscribers asked all of us to say the phrase in a chorus boldly. We did so. Everyone liked it. Thus, it is not our idea. It is the idea of our subscribers.

Question 6: After you cook the food you all in the team eat togther and then donate to folks at old aged home. How did you get this idea?

Answer 6: When we started our channel, we prepare food in a smaller quantity. Later when the number of subscribers increased and the views increased, our income also increased. Then we cooked more food and donated to poorer people, as we believe that when we have excess income we need to support our community. But we did not show our donation in our videos. Once again our subscribers complained that we cooked a lot of food and we ate them ourselves. Only then we started showing how we give away to the needy ones. We also show how our subscribers can donate direct to such charities.

Question 7: What is your future plan?

Answer 7: Our plan is to satisfy our subscribers. We will do whatever they ask us to do in this youtube platform.

Question 8: What is the secret of your success?

Answer 8: First of all our unity is our strength. Secondly, our subscribers are those who correct us when we make mistakes, who encourage us when we do something appreciable

\section{DISCOURSE ON USES GRATIFICATION THEORY (UGT) AND VILLAGE COOKING CHANNEL (VCC)}

The discourse will be done under the following three aspects:

1. Audience Choice: Firstly how the choice of the audience about the content directs the media to shape itself.

2. Motive of Choice: Secondly how the motive of such choice by the audience indulge in satisfying their various needs, such as physiological, psychological, social and self-actualisation needs.

3. Technology and Methodology: Thirdly, how the availability of new technology, internet, shapes the method of media production

\section{Audience Choice}

Audience feedback plays a huge role in their work, says Subramanian. "Everything from sound quality to the kind of rice (Basmati) that we use for biryani, has been the result of our viewers 'comments," he says. After taking three days to research and shoot, Subramanian and the team edit the next day. "Uploading a 10-minute clip can take between two hours and half a day, depending on Internet connection."

"More than one crore subscribers, we are happy that we have got people who consider our victory as theirs. It's something. That a team like us from a little-known village could achieve this," says Subramaniam. When they reached one crore subscribers, the team met Chief Minister MK Stalin and donated Rs 10 lakhs from their earnings towards the CM Relief Fund.

The number of audience grew when they stopped imitating other programmes and started have uniqueness of cooking in a traditional way. VCC uses village surroundings, the fields, the canals, the mountains, the village street as the backdrop. VCC uses traditional equipments like grinding stones, natural spoons and the traditional ways of grinding. VCC also uses natural products in their food making. They cook in a large amount and serve to the poor. All this uniqueness came in their production, gradually, as customers as audience give their comments. By constantly reading the comments of the subscribers, learning from them and shaping their production according to the demands of subscribers, have brought them to this height. 


\section{Uses Gratification Theory and Village Cooking YouTube Channel - A Discourse}

\section{Motive of Choice - Satisfying needs \\ Physiological needs}

As explained in Abraham Maslow Theory of hierarchy of needs, physical needs such as food, clothing, shelter, safety and security come as first basic needs of human beings to get satisfied. Among those needs food comes first.

\section{Psychological needs and Social needs}

Tamil people all over the world, are proud of their traditions. Cooking the traditional food in the traditional ways capture their minds and demand them to be part of that group that supports the concept. That is why they cling on to the channel to satisfy the need of affiliation to this community. In the words of the head of channel, Subramanian, it is noted that these traditional dishes bring a nostalgic value for their viewers, especially for those who have migrated from villages to urban areas.

They hit modern population also by cooking exotic dishes like Arabian mutton biriyani and other north Indian sweets such as rosogollas. In this way, the try to encompass different consumer sectors.

It can be noted that there are separate fan following for Ayyanar who grinds things in stone grinder. The comments praising his grinding skills stand as proof for this fan following. A separate community is formed to appreciate his skill. Another example is Muthumanicam's expert onion chopping technique. It is so popular that he has a separate fan following.

When the channel made their first video about cooking the winged termites, their intention was to share their childhood experiences. That was their way of reliving their childhood memories, telling the world how they lived as kids. This aroused same sensation in the minds and hearts of the audiences and a sense of belonging

\section{Technology and Methodology of Media}

It has to be noted here that VCC videos have been produced with three cameras, giving feast to the eyes, capturing the verdant surroundings of the village areas. The show starts with firewood stoves set up from scratch. The videos are shot in the open fields in the neighbouring villages. The colourful videos give satisfaction for the eyes of the customers and the food brings saliva to the mouths of the audience. The easy availability of videos in youtube channel make things easy to exercise their freedom of choosing the appropriate content that they want to satisfy their needs.

\section{E. FINDINGS}

1. The comments of the subscribers are the feedback for the producers to keep sharpening their production to make their product satisfy the customers.

2. The rapid growth of subscribers show that when the channel try to satisfy the needs of customers, the customers flock in there to get satisfied. It is not only increase of knowledge about cooking, but also feast to the eyes of the customers to see the enthusiasm and traditional way of cooking.

3. VCC channel also touches the heart of customers when the food is served to the orphans and poor old folks.

4. The aesthetics of video making and the viewing of food making satisfy the visual and taste needs of customers.

5. The channel hits traditional and modern viewers, thus building various communities for them to find their suitable content and satisfaction of specific needs.

6. By having separate fan following, the artists prove that different section of audience desire for different needs to get satisfied.

7. The paradigm shift from the importance of media to the importance of people, thus proved by how subscribers direct VCC channel to their success by choosing its content voluntarily and get satisfaction from viewing them.

\section{F. CONCLUSION}

Uses Gratification theory explains that audience is free to choose the options from the content available in front of them and that each one has different motive of satisfying their needs by choosing such specific media. It can be found by the aforesaid discourse that audience choose this channel to satisfy their needs which ranges from physical, psychological and social, consolidating cognitive, affective and behavioural needs. The technology helps audience to choose their content freely and thus proved that every person who became the subscriber has their inner motive of gratifying their specific needs. Thus, it could be accepted that a paradigm shift has happened putting people first over media. 


\section{Uses Gratification Theory and Village Cooking YouTube Channel - A Discourse}

\section{REFERENCE}

1) Uses and gratifications theory retrieved from https://en.wikipedia.org/wiki/Uses_and_gratifications_theory as on 16.09.2021

2) Gusfield, Joseph R. (1994). The reflexivity of social movements: Collective behavior and mass society theory revisited (1 ed.). Philadelphia: Temple University Press. p. 60. ISBN 978-1566391870.

3) Katz, Elihu, Jay G. Blumler, and Michael Gurevitch. "Uses and Gratifications Research." Public Opinion Quarterly 4th ser. 37 (1973-1974): 509-23. JSTOR. Web. 14 Oct. 2011. <http://jstor.org/stable/2747854>.

4) McQuail, Denis (2010). Mass communication theory: an introduction. London: SAGE Publications. pp. 420-430. ISBN 978-1849202923.

5) West, Richard L., and Lynn H. Turner. "Uses and Gratifications Theory." Introducing Communication Theory: Analysis and Application. Boston: McGraw-Hill, 2010. 392-409. Print

6) Stafford, Thomas F.; Marla Royne Stafford; Lawrence L. Schkade (Spring 2004). "Determining Uses and Gratifications for the Internet". Decision Sciences. 35 (2): 259-288. doi:10.1111/j.00117315.2004.02524.x.

7) Leung, Louis (2013). "Generational Differences in Content Generation in Social Media: The Roles of the Gratifications Sought and of Narcissism". Computers in Human Behavior. 29 (3): 997-1006. doi:10.1016/j.chb.2012.12.028.

8) Nainar, Nahla (2020). This YouTube channel by Indian farmer-chefs features feasts from the village and beyond. The Hindu. Retrieved from https://www.thehindu.com/life-and-style/food/online-cookery-show-by-a-team-of-indianfarmer-chefs-is-a-big-hit/article31415819.ece as on 17.09.2021

9) Muralidharan, Kavitha. (2021). Tamil Nadu's YouTube masterchefs: Village Cooking Channel's dream journey. The NEWS Minute. Retrieved from https://www.thenewsminute.com/article/tamil-nadus-youtube-masterchefs-village-cookingchannels-dream-journey-151894 as on 17.09.2021

10) https://socialblade.com/youtube/c/villagecookingchannel retrieved on 17.09 .2021

11) https//www.youtube.com/watch?v=-YCQk_mFTSI retrieved on 17.09 .2021

12) https://www.simplypsychology.org/maslow.html retrieved on 19.09 .2021

13) https://www.youtube.com/int//en-GB/yt/about/press/ as retrieved on 19.09.2021

14) https://en.wikipedia.org/wiki/YouTube as retrieved on 19.09.2021

15) http://www.journalrepository.org/media/journals/BJAST_5/2015/Apr/Ensour832014BJAST11956.pdf as retrieved on 19.09 .2021

16) https://www.semrush.com/blog/youtube-stats/retrieved on 19.09 .2021 